\title{
“The act of reading is a bodily experience": an Interview with Mia Gallagher
}

\author{
Hedwig Schwall \\ KU Leuven, Belgium
}

Copyright (c) 2021 by Hedwig Schwall. This text may be archived and redistributed both in electronic form and in hard copy, provided that the author and journal are properly cited and no fee is charged for access.

\begin{abstract}
With Shift Mia Gallagher put together a collection of short stories which have been in the making for about thirty years. As many stories had been published separately in journals, they were given an overhaul to fit the new context: narrative perspectives were rewritten, layers added, so that the fifteen stories formed a new composition, variations on a theme. The collection forms a fugue building towards increasing weirdness, using faery tale techniques and magic realism to illustrate different shades of the uncanny. Emotions, originating in the protagonists' unconscious, in a family's past, whirl around yet are tightly structured. Gallagher's prose is physical but focusing on the in-between: people's perceptions shift, gender is fluid, objects metamorphose constantly. Her aesthetics are inspired by Baroque theatre, David Lynch and Francis Bacon.
\end{abstract}

Key Words. Shift, metamorphosis, gender fluidity, David Lynch, the uncanny, smell and skin, magic realism.

Resumen. Con Shift Mia Gallagher recopiló una colección de cuentos que se habían estado gestando durante unos treinta años. Como muchas historias se habían publicado por separado en revistas, se revisaron para adaptarse al nuevo contexto: se reescribieron las perspectivas narrativas, se agregaron capas, de modo que las quince historias formaron una nueva composición, y variaciones sobre un tema. La colección forma un edificio de creciente rareza, utilizando técnicas de cuentos de hadas y realismo mágico para ilustrar diferentes tonos de lo siniestro. Las emociones, originadas en el inconsciente de los protagonistas, en el pasado de una familia, se entremezclan pero están estrechamente estructuradas. La prosa de Gallagher es física, pero se centra en lo inter-medio: las percepciones de las personas cambian, el género es fluido, los objetos se metamorfosean constantemente. Su estética está inspirada en el teatro barroco, David Lynch y Francis Bacon.

Palabras clave. Shift, metamorfosis, fluidez de género, David Lynch, lo siniestro, olor y piel, realismo mágico. 
Mia Gallagher is the critically acclaimed author of two novels, HellFire (Penguin, 2006), awarded the Irish Tatler Literature Award 2007, and Beautiful Pictures of the Lost Homeland (New Island, 2016), longlisted for the 2016 Republic of Consciousness Award. Shift (New Island, 2018), a collection of her award-winning short fiction, was longlisted for the 2019 Edge Hill Prize and shortlisted for the 2018 Irish Book Awards. Mia's stories have also appeared as chapbooks: Relict (Ennis Book Club Festival, 2020), Quasimodo (Spolia, 2014) and You First (South Tipperary Arts, 2005). In 2016 Mia guest-edited the Fear \& Fantasy issue of The Stinging Fly.

Recent publications, published in 2020, include Kaleidoscope II (EFACIS), Encounters in Greek \& Irish Literature (Cambridge Scholars), and fiction anthologies The Art of the Glimpse (Head of Zeus), The Music of What Happens (New Island) and The Globe and Scales (Marrowbone Books). Mia's reviews, articles and essays have appeared in numerous publications including The Irish Times, The Guardian, The Stinging Fly and Circa, and she reviews books regularly for Arena, RTE Radio's arts show. In 2020, she was commissioned by the Ennis Book Club Festival to curate an exhibition of artworks from the Arts Council of Ireland's permanent collection and write a story, "Relict", in response to the works. In 2019, she was invited to deliver the annual Bray Literary Lecture in partnership with The Stinging Fly.

Mia has also worked as a theatre artist, touring nationally in Ireland and travelling to the Czech Republic, Italy, Greece, France and the UK. She has received several Literature Bursaries from the Arts Council of Ireland and is a contributing editor to The Stinging Fly. In 2018, she was elected as a member of Aosdána, an affiliate of Irish artists recognised for their contribution to Irish culture and society.

Mia was the inaugural Writer-in-Residence with the Leuven Centre of Irish Studies in March 2019.

Hedwig Schwall: Thanks for taking time for this interview. I suggest we focus on Shift, your most recent book, as I understand it is a collection of short stories, which has accompanied you from the moment you set out to write till last year. So, it somehow covers a good stretch of your development.

Mia Gallagher: Yes. I wrote the first one in 1989 and it was published the following year in the Sunday Tribune. The most recent one was written in 2017 - completely new, it hasn't been published before - so it's almost 30 years of work. Most of the stories were published previously, but I reworked them for the collection. I was working with a new editor, Dan Bolger from New Island, so that influenced things.

Some edits were slight copy edit changes, like with "Polyfilla", changing syntax or some language, tightening it here and there. In other stories I changed the perspective, like in the title story "Shift" I moved from first to third-person narrator. That then suggested a few smaller changes, but it stayed pretty much similar to the original. In other stories I added in a layer. I felt there was something missing. A few stories had been published in a much shorter form than their original drafts, because often with story competitions they have word length limitations. Both with "Shift" and the final story "With Soldiers, in a Cup" I went back to the original longer version, having done a much shorter version in the interim, but I brought what I had learned from the shorter version. In 2013 "Soldiers" was published as a chapbook, "Quasimodo", which was 3,000 words - I went back to the original 10,000-word version; but in the shorter version there was a certain tone I liked, and as I picked that up again it brought another layer of content. So, ranging from a really light frisk-over to a more thorough reworking: nearly all of them had work done on them. 


\section{HS: Is there a rationale behind the order you put the stories in?}

MG: Absolutely. Like anybody else I visit the same themes over and over. I wanted to organise and choreograph the collection so that the returned themes would feel like conscious revisiting rather than repetition. The way I arrange the stories is a matter of variation in atmosphere. In order to get this, I work quite instinctively and intuitively and I work kinaesthetically - I mean by this that I really listen to my emotional and physical response. For me, books are not sequences of words; they are not an intellectual thing, they are physical experiences. The act of reading isn't an intellectual experience for me, it's a bodily experience. This probably comes from having worked a lot in the theatre. The big question - which comes from working in theatre - is how do I want the piece to work on the audience? How do I want them to feel every step of the way? Where do I want to leave them at the end of the show? My theatre practice influences my writing, which is then a matter of creating an experience rather than a text. I always want the reader to participate in an atmosphere. I can have no control of how the reader will experience it, but as I carefully reread my texts I do this in a double way, first the emotional one (as a reader), then the technical one (as an editor). The first is carried by the experience, like "I am really bored here, it needs something more" - so that must be changed; the second is more a matter of line-editing.

\section{HS: The stories are very varied - some are realistic, others completely surreal, others again magical realism. How did you arrange them?}

MG: I felt my way. My approach was influenced by my experience guest-editing an issue of The Stinging Fly ("Fear \& Fantasy", Winter 2016). In that issue, I was casting out for horror, fantasy, apocalyptic work, stuff that maybe wouldn't necessarily end up in The Stinging Fly though there are some fantastic Stinging Fly authors who were already touching on this kind of material. In terms of technically sequencing the material for "Fear \& Fantasy", I laid the stories out physically on the floor of my room, so I could see the first line and the last line. This approach was in the back of my mind when I set to editing and compiling Shift. I have a really brilliant agent, and he said to me a long time ago, when I was putting together my first attempt at a story collection: "make sure you mix third person and first person, male and female voices". I used that as a guide too. Some of my point of view editing choices came from wanting a firstperson male at a certain point, rather than a third-person male.

Thematically, I think I have two suicide stories in this collection, a couple of mental health stories and three "weird” stories. I'm interested in the Baroque as an aesthetic organising approach. By that I mean you have curlicues and elaborations, but it comes back eventually as a sense of equilibrium. It's not the classical approach of pure equilibrium, there is always a bit of chaos that has to be whirled around before it can settle into balance. I am also thinking about the idea of fugue, repetition, building towards increasing weirdness so having the least weird stories in the beginning and making them more and more weird. The first weird story, "Hello My Angel”, starts very prosaically. The middle weird story is psychological; the third and weirdest story comes toward the end. It is a futuristic story.

Again, the collection's structure is inspired by the theatre and the idea of retour: the first weird story comes at the end of the first act, and before the climax, the cauldron of the third act, you have the weirdest story: "[Pinning Tail on] Donkey". In between I spaced the mental illness and the suicide ones, I also alternated first and third person, male and female narrators. The ordering was not a separate thing but an integral part of the rewriting; I was thinking about it all the way through. So, I was happy when the reviews considered it a proper book. It is like in a sweet shop, you might like this sweet, but not another; yet they belong together. I was really 
impressed by Danielle McLaughlin's collection Dinosaurs on Other Planets. I always feel kind of morally responsible for my work; I want it to be out there with a really good and honest intention. McLaughlin had that integrity and coherence.

\section{HS: The general title of book is Shift. That's a great title, with so many connotations ...}

MG: I have to thank my husband for that title. "Shift" is the most heartfelt story of them all. When people talk about the collection, the stories they feel most appealed by are "Departure" and "Shift", and I too have a real fondness for it. It was originally a long story, called "Changing Gear", because it is about a driver and about a transgender person. Their gender identity is slightly ambiguous, but it's mainly through clothes, so transvestite. Before that, the very first title was "Taking Instruction", but my agent thought it was a bit weak, so I changed it to "Changing Gear", which was funny, a deliberate gag. Then it became a very short story titled "Maybe", but after a while, I thought that was a bit of a cop-out of a title. Then I was bashing around different ideas and I can't remember who thought of "Shift", whether it was me or Seán, my husband, but he definitely convinced me it was a great title for the story.

Originally, the whole collection was going to be called Lure, because I wanted a sense of seduction. But "Lure" was a trickier story to get working, and as I was struggling with it I thought this better not be the title story in case it doesn't work. So I told my agent about that and then about "Shift" and he immediately said "yes", and I thought so too, because then I realized there are all these shifts and gears. The design of the book by Anna Morrisson (in London) is amazing. It has this little sea horse, but the sea horse is mechanical, so it's cogs shifting. For me the connotations of "shift" are "change"; then there is the [John Millington] Synge connotation of shift as an item of woman's clothing, like a petticoat or a slip, worn next to the skin, which of course has that scandal connected with it. Shift is also an Irish idiom for (depending on where you come from) kissing somebody or fucking somebody; there is carshifting gear; you can also move things, literally or mentally - you can have a perception shift, a paradigm shift...

\section{HS: You can have a shape shift?}

MG: Yes, of course, I am fascinated by metamorphosis. And the seahorse is androgynous; they are hermaphrodites. So, yes, I am very interested in gender, non-binary gender. So, yes, that was shift. It just felt right, completely.

\section{HS: You use quite often myth - a "logical" move if you want to represent metamorphosis, basic forms of change. Some stories have a fairy tale atmosphere to them. What is your take on these age-old genres?}

MG: I suppose one of the first real influences, if that's not ambitious to say, but the first contemporary writer that I remember influencing me, as an adult, is Angela Carter. I had a fantastic lecturer in college (Stephanie MacBride). I had read some Atwood stuff and Stephanie lent me Carter thinking I would get it. The first novel I read was The Passion of New Eve amazing prose! I also liked Gerard Manley Hopkins. I loved the wordplay, the richness, the assonance, the movement and the dynamism; things morph constantly. But to go back to Angela Carter, she uses fairy tales a lot, and I like her. Also, I thought the film that Neil Jordan made based on The Company of Wolves fascinating. I always loved ghost stories, fairy tales, the macabre, the uncanny, the strange. I was a strange child, so I could identify with that. As a kid I hated reading anything that was realistic. What's the point? Literature has a role to push boundaries. 
I am very interested in what's magic, the things that cannot be seen but are intimated. In Shift there is a lot of fairy tale material, there is a succubus, a demon, more like an incubus, there are strange walls that absorb people. This is more leaning to a Japanese sensibility of the strange rather than European, maybe? When I think about "Hello My Angel”, I think of Japanese ghost stories: they talk about haunting in a different way from the European ones. I also have a kelpie, which is a Scottish water demon; and Red Riding Hood; and Beauty and the Beast. "Polyfilla"'s red shoes refer to that fairy tale idea: the woman who is punished because she expresses herself and does not live up to the society's expectations, except she is punished but she is also the punisher here. While a story may be "realistic" in tone, a lot of these images just come in; you talk about the phantasm; well, that really pushes through with me. I find myself drawn towards images, yes, it has to be red shoes - my writing is not pure naturalism but happens in a slightly different realm: I like what is uncanny, a little bit off.

HS: In Kaleidoscope many writers say they use material from their life but the writing is not autobiographical. In your contribution to that website you said that the short story "Departure” was autobiographical. What do you mean by that?

MG: Yes, “Departure” is very autobiographical. I haven’t made the narrator different from me. In all my other stories, the narrator is NOT me. They are all projections of parts of my unconscious, which I explore. But then, "Headhunter", which is set in prison, is also quite autobiographical. I used to work in a prison as an actor who did modelling for the art classes. For legal reasons I had to change some things. What came out is a story about "the Bear", someone who is very close to somebody I met in the prison. But I changed my role into that of Sonia, a visual artist who works with the prisoners more directly than I ever did.

\section{HS: Sonia teaches painting. Aren't you a painter as well?}

MG: No, I wouldn't say I am a painter. I have painted but I paint so little now, and I think this was a decision I made in 1989 or 1990 - which was interesting because it was after I had written "Departure". When I did paint, it was just for myself; I would never define myself as a "painter". Looking back, I would always say I am an artist, but painting is a practice. My husband is a painter; he has his technique and he is really skilled. I do my work through performance or writing. I have worked in art colleges and I really relate to painters. I enjoy the viscerality of it, but for a verbal artist like me the frustrating thing is you can't portray the simultaneity of things the way painters can. That's a great limitation. The other great limitation of language is that so much happening in the inner world is non-verbal; it's sensation. But that's a challenge that I enjoy. Writers use language to create a simulacrum of simultaneity and of sensation. Take Francis Bacon: all his work is about sensation. In a review recently, not of my work, my name was mentioned in the same sentence as Bacon. I was very grateful because I really relate to his work; I always did, since I was a child. There is a real honesty there and a rawness, and at the same time it is beautifully formed, it's not just random.

HS: Bacon represents people as not-entities, more cut up and constituted. I could see a similarity with your characters, like your Bear character, who has to come to terms with his past via painting; or the protagonist of "Lure", Maggie/Magpie, who suffers from the "clusterfucking” in "the pathways of her most unusual brain”. Both are institutionalised, both break out in their very colourful perception of the world. Actually, it seems you often focus on the marginal characters, people with mental complexities and emotional difficulties, whom you beautify. You somehow turn poor patients into brave soldiers of an internal battle, who become outstanding, dignified people. Is that an intention? 
MG: I feel very moved by you saying that. I do not consciously set out to do that. I am not on a reforming mission, but I try to feel my characters as human beings. Everybody experiences pain, but pity too is a terrible thing. Pity forgets about Otherness, and I suppose I am fascinated by another's experience of living that I can't have, with the fact that somebody's perception is very different to mine. How do others see or experience the world? I am fascinated by that. It is a curiosity which complements being a performer. It's about being interested in going to another space, or rather about opening up a space in myself.

I worked in a treatment centre for 13 years during the [economic] Boom, when the type of people I was working with were excluded from the public discourse. And when they were spoken about it was in really insulting language. There were some really tricky characters and, like in the prison, ultimately most of them - ok, there are sociopaths and psychopaths and there are ruthless and cruel people - but they're people. Sometimes when I start writing about a person the process seems to bring secrets to light. When I go back over the story, I realise that I had a judgment against the character, which in fact is more about something to do with myself - maybe my judgment has influenced the judgment the character has about him or herself, which has made them act the way they do. So, what I try myself and teach students to do is to give as much leeway to the characters as possible: let them construct themselves. I try to treat them really seriously, to honour their logic. And when I get to know them, they start developing their own behaviour - as in real life, somebody can have bad ideas about themselves and that may affect their behaviour. About the people with mental health issues, it's really tough. But it's also wow. They relate to things in such a different perspective. Maybe in a hundred years' time we will realise how schizophrenia gives people access to an awful lot of layers we don't have access to, and we are so much the poorer. And at the same time there is also a real role for psychopharmacy, so that people don't damage themselves.

HS: In some stories you refer to intergenerational material, like "Magpie" notices that she has inherited elements of her father, Wandering Duncan, and his sisters and so on. And, also, in "Soldiers" you refer to the fact that the daughter did exactly what the mother did. Is this something that plays in your mind?

MG: I'm obsessed with family. Once I start looking at a character my first question is always who is their family? Because the family gives me the character. Family is the biggest influence on a person. I am genetically the result of my parents, and all those generations forking back to wherever. Also, I am a product of my parents' behaviour, their emotional states when I was various ages, their fears, hopes. I am not neutral. Myself - "self” is dialectic with others, my parents and all their generations forking back out to whenever.

So to go back to this idea of the individual. Are we ever truly individual? We are in so much contact with other people all the time.

Once I start digging into family I feel immediately on safer ground. So, that's what I need, to understand who this person is. I think as well of class, ethnicity, geographical background, location, money, the jobs people in a family had, the ancestry, their migration habits. These for me are the basic things that create character. There is a thing in screenwriting, it's called the Character Toolkit. Someone may be motivated by the power of love; that may well be, but a much more basic component of character is, what was the mother like? Where did she come from? But also interesting is how do people relate to money and class - in Ireland it's not so tangibly codified as it is in the UK, but every culture has a class system, people in power, disadvantaged people. I have always been interested, ever since I was a young child, in power, in what's equal, what's unequal, how they play out. 
HS: We are not individual but dividual, or better "interall": neither undivided nor dual, we are always "inter", in between things, and as we constantly assimilate elements from our surroundings we constantly change. So I loved the passages in Shift where the focus is on interaction. I'm just giving an example here from the story "Pinning Tail on Donkey": "I could feel their no, yes, loserstatus projecting out of them with such dangerous intensity it could almost be touched. [...]The invited one's blink, burn into the code of our cells, altering us forever" (Gallagher, Shift, 209). The children's sensitivities are very concrete here, and it's great how the immaterial (gaze) and materiality (burn into our cells) mix and mingle in your characters' interactions. But there is another story I like even more, it is all about sex and has the intensity of an Eimear McBride, "Found Wanting”. Didn't you ever think of submitting that story to a competition?

MG: I had submitted an early draft of it to the Fish International Short Story Competition. It didn't make it to the top 10, but it was published in their anthology that year as an Editor's Choice. I was a bit embarrassed after I'd written it, because it's all so directly about the intricate effects of sex. But then I did more work on it for Shift and the power of passion that was very strong when I wrote the first version (in my early thirties) got a harder, colder layer now that I am in my early fifties. The fifteen years in between seemed to have done the story good, the colder layer gives a good counterbalance to the passion in it. But it's still about a character who is obsessed with sex. I am sometimes surprised people like it.

HS: The protagonist of "Found Wanting" is very convincing. When she observes how sex makes her real - "As if more of my self was being pared away, but whatever was left was more me" (Gallagher, Shift, 57). That's metamorphosis all right - even a mystic experience?

MG: Yes! I originally wanted to explore Tantra. Because sex is so intimate, it's not just about procreation, or just about orgasm, especially for women. Maybe it is, paradoxically, the very thing that allows someone to experience their - individuality? It's so intimate, so inside, again especially for women. Something is being reached. Hard to talk about it without sounding horribly Mills and Boonish! Working with my editor Dan Bolger on this version of it helped too; I had to really find physical language that might communicate to the outside world what I was thinking that might be happening. But it's curious - or maybe not - that it's especially women who relate to this story. The story is about this physical madness: the guy is completely unsuitable, but there is that weird rush of pure biochemistry and obsession, and then there is all this strange, childish, jejune behaviour - like not daring to meet somebody's eyes - so yes, it is a fun and funny story.

HS: It's a great one. We were talking about sensation, and you are very strong on the five senses. Smell is prominently present in many of your stories. Is the olfactory aspect helpful, because it obliterates boundaries, because it connects?

MG: Oh, yes, that's a really good way of describing it. That's accurate. You know I'm very literal that way; the senses are very concrete with me. I did a workshop with a New Media Company in the early 90s. And Áinne Burke, the woman who set up the company, was quite visionary. She was a visual artist; she got funding from the European Broadcasting Union to develop a project on audiovisual creativity for television producers and directors in Ireland. The storytelling style there had been relatively unsophisticated on a visual art level, in that it hadn't been informed by visual art history or ideas. Áinne did workshops with the directors and producers, and she talked about the five senses. To me smell is really evocative, and it is also a 
time traveller. Think of that beautiful scene at the end of Brokeback Mountain, where the lover who is left alive at the end smells his dead lover's shirt. We've all done that - we were attached to the smell of our mother's milk. I remember my mother always smelling beautiful when she went out, to a party or whatever; she had a particular perfume. I bought her a wrap a few years before she went into care, so her smell was on it, and when I was sitting with her in the hospice, I used to put her wrap around me, to keep her more with me. And after she died I wore it quite a lot to keep her smell. That's individual. Everybody has their individual smell. That is individual.

HS: Individual, but shareable? So conveyable, via jumpers, shirts, wraps... that it can be a ghost presence even after death?

MG: Maybe our essential selves are our essential oils. Maybe our true self is our smell. People get a smell off other people. For Magpie in "Lure", smell is quite important; the idea of all these young girls covering over their natural scent with deodorant, hair spray and so on. I am not talking about sweat - that's different. But, ultimately, we, human beings, are animals, we get the pheromone that we like, so we want to be around that person or we don't. Similarly, I have had reactions to people who are perfectly fine people but I just don't want to be around them because I don't like their smell. I don't even think about it; it's just that my skin is prickling and I am restless.

HS: Apart from smell, touch seems very prominent in your toolbox of senses; and taste goes with smell too - actually you are very synaesthetic, as in "He daubs the paint on with shouts of the brush" (182), or 'He is sweating so much Sonia can taste it” (Gallagher, Shift, 178), or "He tells it so well I feel the savour of it pop on my tongue" (Gallagher, Shift, 269, interviewer's emphasis). Like textiles, skin can convey quite a bit of our "self”.

MG: It is interesting that you mention that. I've had different issues with my skin at different times in my life. When I had a first go at making this collection in 2002, I had a bad kind of rosacea or acne; I felt very self-conscious because my skin looked awful. I remember showing those first stories to a friend of mine who noticed: "Oh my god skin is everywhere". But this thing about skin played up even earlier on in a big way: when I was eleven I was supposed to see a radical version of Macbeth in the Project arts centre, at the time the Eurovision was on, but I came down with chicken pox on the very day of my $11^{\text {th }}$ birthday and was in bed for about three weeks. And suddenly - I was pre-pubescent - I thought heaven does not exist. Life is just all struggle; and there and then that feeling made me lose my faith in orthodox organised religion. Later again, in 1989, my skin played up in a big way. I went to Nicaragua in a misguided attempt to save the world. It didn't really go well; I got really ill and almost died. I had been given very heavy medication to survive. I was really weak and I lost some hair, and six months later I started getting bad acne for about a year. Then I had the later acne attack in my mid-thirties. So yes, skin plays an important role in my perception.

HS: Skin forms a boundary between the self and the other, inside and outside world. This difference is not always clear in your stories, like with the girls in "Lure".

MG: The bitches!

HS: Indeed, but, those bitches - are they real social bodies or are they part of the protagonist's mind? 
MG: I don't know... [big smile]. I like readers to bring their own interpretation. Either interpretation is totally valid. There are no bad interpretations - that is not what I am concerned about. The girls are just there; you give them the shape you want.

\section{HS: The same goes for the kelpie's bridle. Is it a real thing or only an imagined "dagger" Magpie sees before her? Something made of beer can lids?}

MG: Ah, that "bridle" - this is where I am literal. Particularly with objects - I pay great attention to objects. I think, right I'll write this, and then I have to honour the object that crept into the story. My unconscious has thrown it up; I have to catch it and do something with it. I do not necessarily believe in it immediately but I am committing to it and following it through. I thought about that bridle a lot. It's all about giving the right information on such objects, not too much, not too little. I really love David Lynch and how he can allow a thing be in its own space; he can allow some kind of an event or a character, or an object or a sequence, exist in the frame of his story and simply claim space without having to explain it. I am more on the explaining spectrum than Lynch is. But I leave clues for readers to put the pieces together. Sometimes the way they assemble the pieces matches the way that I think the pieces are assembled, but sometimes they assemble them in a slightly different way. For example, somebody who had read "Headhunter" and at the end thought, oh no ... this man actually killed his brother. Who am I to say? Maybe he did, maybe not - reading can be really private. That's again where experience comes in. Just like the author feels her way towards a character, the reader does too.

HS: For my interpretations of short stories, I always look at the first and last sentence to see what I can do with them, and to see how they relate to the title; they give me major clues, but in the case of "Headhunter" I was really puzzled.

MG: Sure - well, I actually made a little change. The original story didn't have this ending, not even this beginning; it's a story that has grown, based on a reality which kept developing. It's a sort of document, palimpsest: every time I get new information it becomes a bit longer. In this draft there's a new character, a secondary character, who appears right at the end. On the almostlast draft, I'd set up this character right at the beginning in the first few lines. Then it's into the headhunter's story, and then the end, so the beginning and the end actually echoed each other. But as I was reading through the proofs, I realised I had used the same rhythmic structure - of 3-4 lines and then a bigger passage - to start 3-4 stories in a row. They were "You First", then "Headhunter", then "Donkey": all had the same formal structure in terms of how the opening looked on the page. And I only saw it on the final proof, because of the page layout - there are fewer words. Structurally, and visually, they were too similar. So, I decided to change two. I changed "You First", by moving what had been the opening three-line section onto the next page, and starting it with a longer section. That worked fairly seamlessly. With "Headhunter", I got rid of the first three lines altogether, where the secondary character is introduced. It made the ending more mysterious but I could live with that. In fact, it made the whole more chronological, because the reader only meets that character, like Sonia does, after everything else - instead of being given a flash hint at the start.

\section{HS: When you say structure, do you mean something visual, or something rhythmic?}

MG: In this case, it was visual, but also rhythmic. All three stories had the same rhythmic opening. For me the collection is musical, it has a rhythm. I don't want these three movements to start in the same way. I want them to be different. It is guided by the principle of difference 
that I use around perspective, male-female, around even the same theme being placed differently. Both "You First" and "Headhunter" are the same length, and relatively short, which compounded the issue. I didn't want them so squashed together with the three openings looking the same.

HS: Very interesting! I usually like a short story because of its structure.

MG: Why?

HS: A good plot or structure creates a sense of necessity, of the ways in which life does its own things. Again, it shows the "individual" in intense interaction, struggling with things, swimming against a flow, or several undertows. The more tightly woven the story is the more I like it ... Some of your stories have these multiple interactions, like the family members in "Soldiers". First, I didn't get it but when you reread it you see more "wavelengths". And, then, suddenly I saw how that final story's structure really feeds the DNA of the family issues. So, the content and the form are interwoven.

MG: I remember reading about Mayakovski when I was in college, and he talked about how revolutionary content needed revolutionary form and I thought that was really interesting. It appealed to me. Also, again, the theatrical effect is important to my prose. I worked with really interesting theatre makers like Ciarán Taylor; he studied in Paris, and his approach is visual physical theatre, where form is important. But for me form only comes after you have shaken up your material as much as possible. You don't do that for the sake of shaking it up, but when you shake things up something new falls out of the cracks. This brings me back to my love for the Baroque: it is the stilled form of what was previously turbulent. Or look at David Lynch, again: he is formally magisterial. Twin Peaks' The Return is the most extraordinary piece of audiovisual art. But it's also extraordinary because he does really silly things. I feel there is always a risk of being silly, but the child is silly and we were all children once. At the same time, I am totally serious about things. But to come back to "Soldiers", the shorter version of it still has two intertwining stories: the dog went in and out of several drafts, and earlier on the ghost wasn't in it so much. Then there is this whole thing about the potential that is unresolved, the narrator's own obsession, which is a layer I discovered when I was rewriting in 2017 and in 2018. That layer suddenly made total sense; it was buried right underneath.

\section{HS: Do you bury things consciously?}

MG: Yes - it's more like I leave them buried, but I also leave little hints of them. I like to pull somebody into a world without explaining the world. I like to pull them into that experience. This comes down to the question of who the narrator is. The narrator or the protagonist knows already so much more than the reader does but they speak directly from experience, so the reader has to fill in the gaps. Not everybody is going to have the patience to do that. But that's okay.

HS: But sometimes you do explain things, as in "Headhunter" when in the case of Bear you talk even of "cathexis". This sounds like straight out of a manual.

MG: Yes, when I came across that word I really liked it. I explain some technical stuff. But in that passage it is Sonia explaining it to herself, not to the reader. 
HS: Oh, I see, I was also wondering which voice that was. In the same story, I didn't get the reference to Charles Lamb. “The institution had got into her soul, like Charles Lamb's wooden desk” (Gallagher, Shift, 186)?

MG: If my agent and my editor had picked up on that kind of reference or been troubled by it I would have explained it. But they didn't. I trust Dan, my editor; he is a very good close reader. So, neither my agent nor my editor needed an explanation. But to explain it here ... When I was studying for my Leaving Certificate (like Abitur or Baccalauréat) in the 1980s we studied prose pieces for English, essays as well as fiction, and one of these was Charles Lamb's essay on retirement. It's really sad, because he was writing about how much he had looked forward to retirement, but then as he was leaving, he looked at his desk where he had been sitting for so long, because he was a clerk, and he felt how the wood had gone into him. At the same time, during the 1980s, I was reading Iron in the Soul by Sartre. And for some reason these two images began to merge into the image of Charles Lamb's horrible desk, where he felt the pedestrianism of just being a clerk, it was desiccating him, it was coming through his skin and turning him into a piece of wood, and this became Sonia's experience in the institution.

HS: But sometimes the connections between your characters and their "personal objects" are very positive, like the marbles in "You First": “Adam's favourite marble is the one that looks like a miniature universe. It sparkles. Deep, deep blue, speckled with silver. Adam loves that deep, deep blue” (Gallagher, Shift, 136). The marbles characterise their owners, like Adam's trust contrasting with his playmate who favours a cat's eye. But this story, like so many in this collection, show an ever-shifting balance in feminine-masculine relations. At least three stories out of fifteen focus on gender venture. Is this part of your exercise of interacting?

MG: I am probably a bit transgender myself. When I was a kid I was fascinated by Viola and Sebastian, the twins in Twelfth Night. I have always loved the principal boy, the idea of the girl who dresses up as a boy or boy as a girl, to have adventures. And later when I was a teenager I loved David Bowie and I was interested in female-appearing men and male-appearing women; that's part of my own personal connection. I always felt gender is a lot more fluid and broader than culture has it; it is historically constructed. I identify as a Cis-female; I am straight. But I also definitely have a sense of there being a masculine streak; I am not totally feminine at all. I am interested in men, but I also write about gay men. Like Adam is gay. I only figured that out getting this collection together, a new line came to me, a reference to his "cruising days". I'd had to change something else because it was too like another story and when I saw the new line, I thought this makes total sense. With Des and Christo in "Shift" it is very, very fluid. The idea of men's intimacy with each other really interests me.

HS: In both stories I was surprised by the sudden kiss. Where did that come from? Adam and George had not seen each other in such a long time and then they suddenly kiss. Des is drunk so that's different.

MG: It's not really a kiss. She is not kissing him; it is a functional thing. She helps him do something; she's helping him to smoke the cigarette. It becomes a kiss, but it is about something else.

HS: Maybe with the smoke she wants to help him die?

MG: Maybe she does. 
HS: My last question is one of the puzzled reader. Some stories I enthused about immediately, others were wonderfully enriched by rereading, but there were still three stories with which I was at a loss: "The Lady Vanishing", "Christopher de la Rosa" and "Pinning Tail on Donkey". I must say when you gave me a hint as to the Vanishing Lady I thought that was really clever: it's all about breath indeed. But I still don't get the Christopher one. Is he a wood sprite, a ferryman from a world of pixels to the one of pixies? Who are the children?

MG: That story I just feel. Even I am not hundred percent sure what the content is; it is more a matter of atmosphere. It felt like a piece of poetry; it felt absolutely real. It makes me feel uneasy, it works on my limbic system, it works in the back of my head. I am very happy for the story to unsettle the reader. That's how I feel "Lynchy" - I am allowing that piece to take its space. Also, it is very short, but I think it fulfils a function in that collection, an interlude I wanted to include. Some people will ask what is all that about, others immerse themselves in the atmosphere, some have said "I am kind of obsessed with that piece". Sometimes I think it's not really a story, more a tonal piece you just read and feel.

HS: Maybe it is time to round off. I loved the volume and gained a lot from rereading the stories. And a kind of overall theme seemed to be love - all those variations of love, erotic and family love, friendship ... If I would write an essay about this collection, I should maybe call it “All kinds of Love”?

MG: That would be a great title: I think it is about love. That's an empty word in itself; you can get sentimental connotations. But it is the experience of love that counts. Love is not about how you feel but about something you do. And it is demonstrated by your actions. I can say to somebody that I love them, but what do I do, to demonstrate that? That is ultimately what it comes down to. Or the other way round: somebody can say they don't love, but they act in loving ways - and that just lifts them. Like say in the last story, there's Steve; he is a gobshite, but he is the one who helps Annie the most. It all comes down to what you do.

HS: Indeed. Thank you very much for these splendid stories and for this interview.

\section{Works cited}

Gallagher, Mia. Shift. Dublin: New Island Books. 2018.

Kaleidoscope: https://kaleidoscope.efacis.eu/writer/mia-gallagher

https://kaleidoscope.efacis.eu/writer/catherine-dunne

https://kaleidoscope.efacis.eu/writer/billy-ocallaghan

https://kaleidoscope.efacis.eu/writer/joseph-oneill

https://kaleidoscope.efacis.eu/hedwig-schwall/writing-

\%E2\%80\%98business\%E2\%80\%99-being-wholly-human

Hedwig Schwall is director of the Leuven Centre for Irish Studies (LCIS). Most recently, she edited Irish Studies in Europe (on Boundaries, Passages, Transitions, vol. 8); the special issue of RISE, the Review of Irish Studies in Europe, on "Irish Textiles" (2018) and The Danger and the Glory (2019), a volume of 60 contributions from Irish fiction writers about the art of writing. 
She is Project Director of the European Federation of Associations and Centres of Irish Studies (EFACIS, www.efacis.eu) and co-editor of "Europe in Ireland" (forthcoming 2021, https://kaleidoscope.efacis.eu/). On 1 February 2021 she launched, together with Marija Girevska, the Anne Enright Translation project https://enright.efacis.eu/. In her research she focuses on contemporary Irish fiction and poetry.

hedwig.schwall@kuleuven.be 